\title{
液状化地盤において複数回の地盤変状を受けた 耐震継手ダクタイル鉄管の挙動検証
}

\author{
森本 皓一 1 ・宮島 昌克 2 \\ 1 正会員 金沢大学大学院 自然科学研究科（†920-1192 金沢市角間町） \\ E-mail: k_morimoto@kurimoto.co.jp \\ 2 正会員 金沢大学教授 理工研究域 地球社会基盤学系（ \\ E-mail: miyajima@se.kanazawa-u.ac.jp
}

\begin{abstract}
埋立地等の軟弱地盤では, 地震による液状化現象に起因して大規模な地盤変状が生じ, 埋設された水道 管にも大きな被害を及ぼしてきた。耐震継手ダクタイル鉄管は継手部に伸縮性，屈曲性，離脱防止性を有 するため, 現在まで地盤変状による被害は発生していない.ただし, 大規模な地震動が連続して発生した 場合に，液状化地盤に埋設された耐震管路が複数回の地盤変状を受けてどのように挙動するか，明らかに はなっていない。本研究では，1995 年に発生した兵庫県南部地震時に計測された地盤変位を用いて，実際 に生じた地盤変状を管路に複数回与えて管路の挙動解析を実施し，管路の挙動を検証した。
\end{abstract}

Key Words : multiple times, ground displacement measurement, liquefaction, ductile iron pipe, pipeline behavior analysis

\section{1. はじめに}

1995 年 1 月 17 日に発生した兵庫県南部地震は, マグニ チュード 7.3 を記録した都市直下を震源とした地震であ り，埋立地を中心に液状化現象に起因して大規模な地盤 変状が発生した．地盤変状が生じた位置に埋設されてい た水道管にも，多数の被害が発生した ${ }^{1)}$ ，その中で，耐 震継手ダクタイル鉄管は地盤変状が生じても継手部が伸 縮または屈曲することで変位を吸収し，さらには離脱防 止機構を有することから, 被害は発生しなかった 1),2). 東北地方太平洋沖地震等, 他の大地震で発生した地盤変 状においても，而震継手ダクタイル鉄管に被害は発生し ていないことから，液状化現象に起因して発生した地盤 変状に対する管路の安全性は十分に実証されている.

2016年 4 月に発生した熊本地震では，最大震度 7 を観 測する地震動が 2 度発生した。埋設された管路に着目す れば，大規模な地震動が連続して発生した場合，管路が 1 度のみならず複数回の地盤変状を受けてどのように挙 動するか，未だに明らかにはなっていない.

管路の挙動検証にあたり，実規模の水道管路を対象と した実験により管路挙動を確認することが望ましいが, 広範囲に発生する地盤変状を実験で再現することは困難 である. 一方で数值解析を用いれば，管路や管路周辺地 盤をモデル化し ${ }^{3)}$ ，地盤変位を地盤モデルに与えること
で，管路の挙動検証が可能となる。また，兵庫県南部地 震前後に実施された航空写真測量により，大規模な地盤 変状が発生した地域での地盤変位が計測されている ${ }^{4}$.

そこで本研究では，兵庫県南部地震で計測された地盤 変位を用いて，実際に生じた地盤変状を管路に複数回与 えて，管路の挙動解析を実施した.

まず，水道管路に被害が生じた位置を解析対象位置と し，被害状況を解析で再現することで，解析手法の妥当 性を確認した. 次に, 解析対象位置に而震継手ダクタイ ル鉄管が埋設されていたものと想定して，実際に生じた 大規模な地盤変状に対する耐震管路の性能を検証した。

さらに，1 度地盤変状を受けた耐震継手ダクタイル鉄管 に対し，同じ地盤変状を複数回与えて管路の挙動解析を 実施し，複数回の地盤変状を受けて管路がどのように挙 動するか検証した.

\section{2. 計測地盤変位を用いた管路の挙動解析手法}

(1) 解析対象位置

兵庫県南部地震後に，兵庫県神戸市から西宮市にかけ て, 沿岸部や埋立地を中心に地盤変位が計測された ${ }^{4)}$. 図-1 に，地盤変位が計測された地域を示す。一方で, 地震後に水道管の被害調査が実施された ${ }^{1)}$. 図-2に, 神 


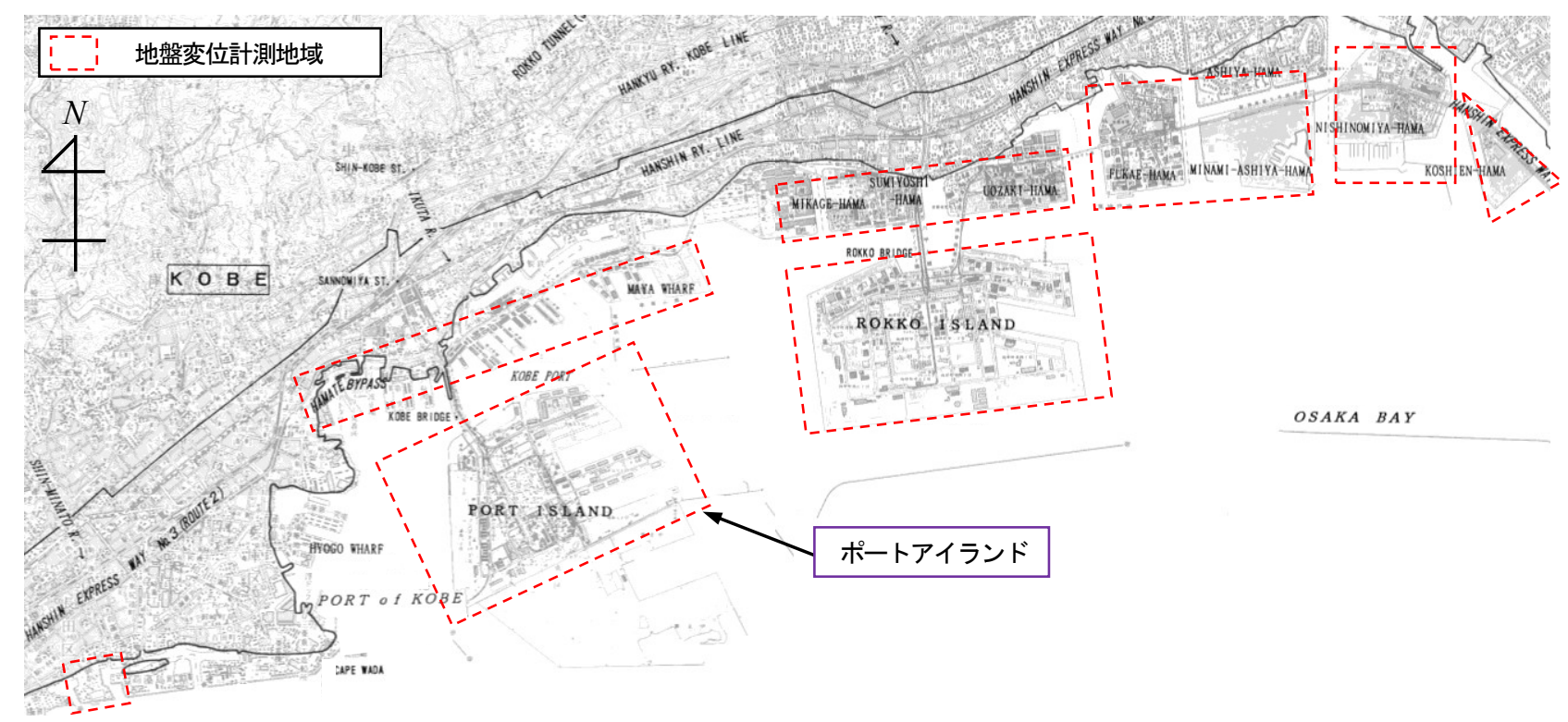

図-1 兵庫県南部地震後に地盤変位が計測された地域 4

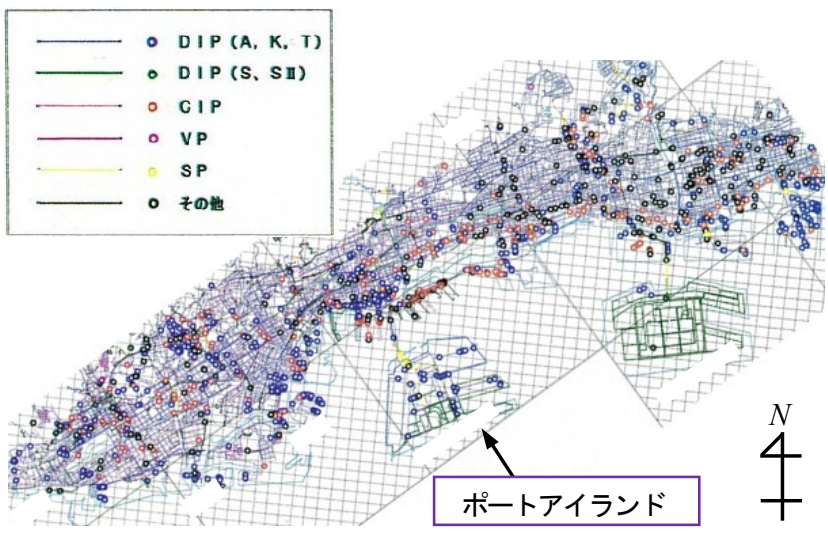

図-2＼cjkstart兵庫県南部地震時の神戸市における水道管被害図 ${ }^{1)}$

戸市における水道管の管種別被害図を示寸．図-2 より， 沿岸部や埋立地で多数の水道管に被害が発生したことが 確認できる.

解析対象位置の選定にあたり，まず直線管路で多くの 継手に抜けが生じた神戸市のポートアイランドに着目し た. 次に，管路が直線上に埋設されており，かつ継手の 抜けが発生した位置を抽出し，位置 $A \sim F$ とした。 なお， 兵庫県南部地震では液状化現象が発生した地域において, 護岸から $100 \mathrm{~m}$ 以内の領域では護岸の移動による側方流 動の影響が大きかったことが確認されている ${ }^{5}$. 本研究 では，液状化そのものに起因する地盤変状を受けた管路 の挙動を検証するため, 護岸から $100 \mathrm{~m}$ 以上離れた人工 島内陸部を対象とした．図-3 に抽出した位置を，区間 長, 地盤変位計測数, 継手の抜け発生数と併せて示寸.

図-3 より, 位置 A では地盤変位計測值や継手の抜けに 関する情報が複数得られることが確認できる．以上より， 位置 A であれば継手の抜けが生じた範囲と生じなかっ た範囲を解析で算出し実際の継手状況との比較が可能と 期待できることから, 位置 Aを解析対象位置とした.

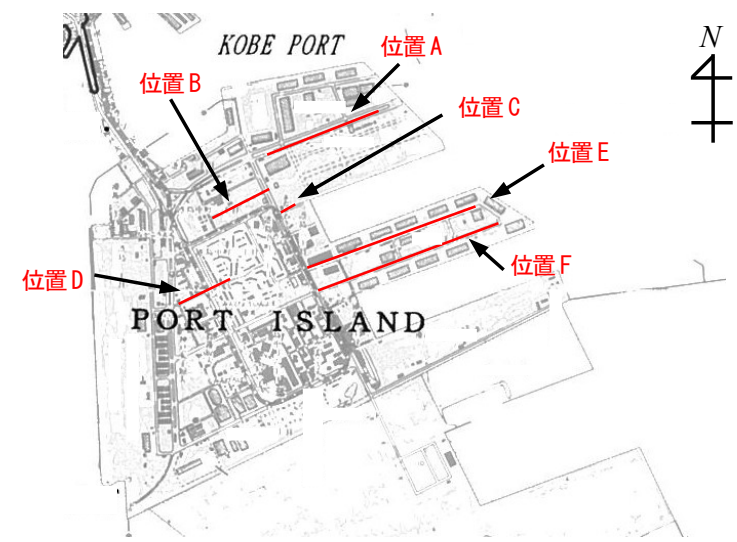

\begin{tabular}{|c|c|c|c|}
\hline & 区間長 & 地盤変位計測数 & 継手の抜け発生数 \\
\hline 位置 $\mathrm{A}$ & $800 \mathrm{~m}$ & 7 & 4 \\
\hline 位置 $\mathrm{B}$ & $390 \mathrm{~m}$ & 2 & 1 \\
\hline 位置 $\mathrm{C}$ & $80 \mathrm{~m}$ & 1 & 2 \\
\hline 位置 $\mathrm{D}$ & $400 \mathrm{~m}$ & 1 & 5 \\
\hline 位置 $\mathrm{E}$ & $1140 \mathrm{~m}$ & 1 & 3 \\
\hline 位置 $\mathrm{F}$ & $1200 \mathrm{~m}$ & 8 & 1 \\
\hline
\end{tabular}

図-3 ポートアイランド内で継手の抜けが 確認された位置

\section{（2） 解析モデルと解析条件}

図-4に，解析モデル，および解析条件を示す．解析 は，汎用構造解析ソフト ANSYS Mechanical を用いて実 施した．管体は剛体要素でモデル化したため, 継手の伸 縮や屈曲のみで管路が挙動するものとした．管同士を継 手ばねで接続し，管と地盤質点とを地盤ばねで接続した。 管路の基点のみ固定し, 計測された地盤变位を地盤質点 に与えることで管路挙動解析を実施した．なお，継手ば ね，地盤ばねの詳細設定は後述する. 


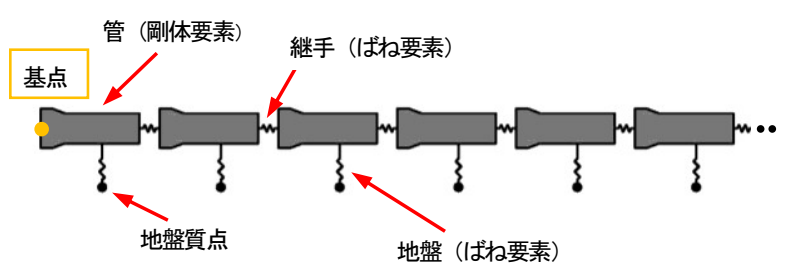

(a) 解析モデル

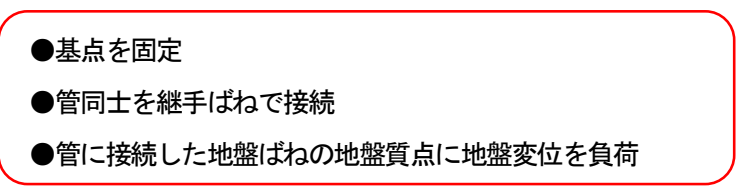

(b) 解析条件

図-4 解析モデルと解析条件

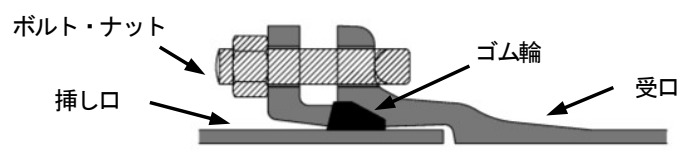

(a) $\mathrm{A}$ 形

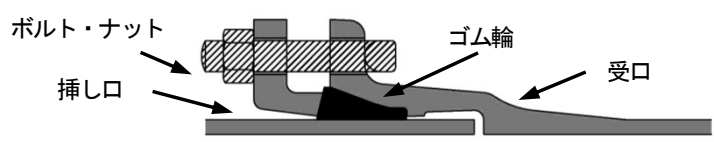

(b) $\mathrm{K}$ 形

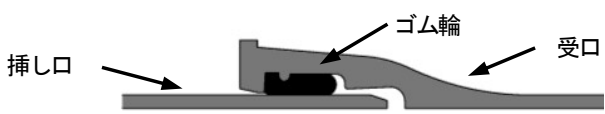

(c) $\mathrm{T}$ 形

図-5 継手の構造

\begin{tabular}{|c|c|c|c|}
\hline \multicolumn{4}{|c|}{$\begin{array}{l}R_{m}: \text { 推定被害率 }(\text { 件 } / \mathrm{km}) \\
C_{p}: \text { 管種 } \cdot \text { 継手補正係数 } \\
C_{d}: \text { 口径補正係数 } \\
R_{L}: \text { 標準液状化被害率 }(\text { 件 } / \mathrm{km})\end{array}$} \\
\hline & A形継手 & K形継手 & T形継手 \\
\hline 管種・継手補正係数 $C_{P}$ & 1 & 0.5 & 0.8 \\
\hline
\end{tabular}

図-6 液状化地盤での管路被害予測式の

(3) 管路モデル

\section{a) 解析対象とする継手の構造}

解析対象位置では，呼び径 $200 \mathrm{~A}$ 形，K形，T形継手 のいずれかで構成された管路が埋設されていた。図-5 に， $\mathrm{A}$ 形， $\mathrm{K}$ 形， $\mathrm{T}$ 形の継手構造を示す. $\mathrm{A}$ 形継手は, 挿し口と受口の間に挿入したゴム輪をボルト・ナットに より締め付けることで止水するメカニカルタイプの継手 であり，K 形継手は A 形継手よりも水密性を向上させ た継手である。一方で， $\mathrm{T}$ 形継手は受口にゴム輪を預け た後に挿し口を挿入することで，ゴム輪を圧縮し止水す るプッシュオンタイプの継手である.

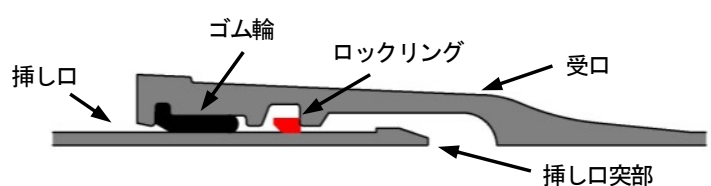

図-7ＮS 形継手の構造

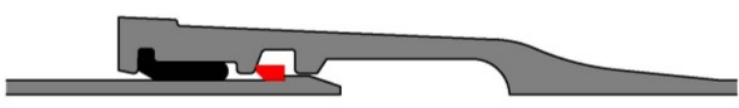

(a) 継手が伸びきった場合

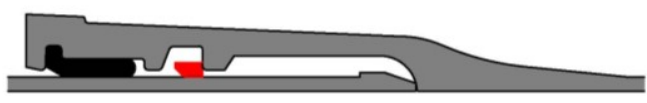

(b) 継手が縮みきった場合

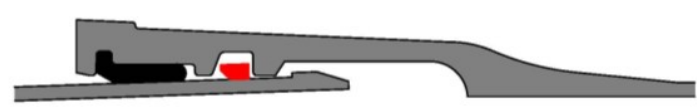

(c) 継手が屈曲した場合

図-8 NS 形の継手挙動

ここで，水道技術研究センターで確立された，液状化 の情報を有しており，から液状化の可能性ありの場合の 管路被害予測式 6)を図-6に示す。本式は，地震による管 路被害データを基に確立されたもので，被害データには 継手の抜けが含まれている， $\mathrm{K}$ 形継手は $\mathrm{A}$ 形継手， $\mathrm{T}$ 形継手と比較して，予測式で用いる管種・継手補正係数 $C_{P}$ が小さいため，管路 $1 \mathrm{~km}$ あたりに推定される被害率 が低くなることが確認できる．以上より，K形継手を解 析対象として解析で継手の抜けを再現できれば，より継 手の抜けが生じやすい A 形，T形継手を対象とした場合 でも，解析で継手の抜けが再現できると考えられる.

そこで，本研究では解析対象を $\mathrm{K}$ 形定尺 $5 \mathrm{~m}$ 管と想定 した．まず，地震後の $\mathrm{K}$ 形の継手状況と解析結果を比 較することで，解析手法の妥当性を確認した．次に，同 じ位置に耐震継手ダクタイル鉄管である呼び径 $200 \mathrm{NS}$ 形ダクタイル鉄管（以下 NS 形）定尺 $5 \mathrm{~m}$ 管が埋設され ていたものと想定して，管路の挙動解析を実施した.

図-7に NS 形の継手構造を示し，図-8 に NS 形の継手 挙動を示す. 図-5(b)および図-7に示す通り，K形継手, NS 形継手共に継手の伸縮や屈曲で管路に作用する外力 を吸収する構造である. さらに大きな引抜き力が継手に 作用した場合， $\mathrm{K}$ 形継手は離脱防止機構を有さないため, 継手が抜けてしまう。一方で，NS 形継手は継手に大き な引抜き力が作用した場合でも，ロックリングと挿し口 突部がかかりあい継手の離脱を防止するため, $3 \mathrm{DkN}$ 


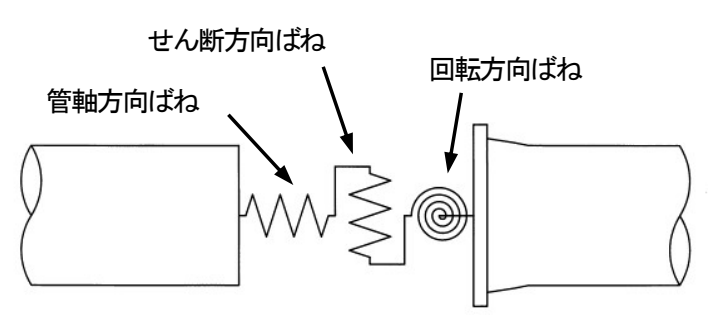

図-9＼cjkstart継手モデル

$(D:$ 呼び径 $(\mathrm{mm}))$ の引抜き力に耐えることが可能 となる。

\section{b) 継手ばね特性}

本研究では，管を剛体要素で，継手をばね要素でモデ ル化した．図-9に，継手モデルの概要を示す．継手の 挙動を表現するために，ばね要素を管軸方向，せん断方 向，回転方向にそれぞれモデル化した.

継手ばね特性は，継手性能試験等 7),8)に基づき設定し た. 図-10に NS 形，K 形の継手ば补特性を示す。管軸 方向においては, 図-10 中に引張方向, 圧縮方向それぞ れの領域を示した.

NS 形を対象とした場合，管軸方向，回転方向におい て，小さな力で継手が伸縮，屈曲する領域の継手ばね定 数を，それぞれ $S_{a l}, S_{c 1}$ とした，一方で，管軸方向，せ ん断方向，回転方向において，金属同士が接触して大き な力を負荷しても継手の伸縮や屈曲が困難な領域の継手 ばね定数を，それぞれ $S_{a 2}, S_{b} \wedge S, S_{c 2}$ とした. 管軸方向， 回転方向においては, 2 つの領域の境界となる継手変位 や継手屈曲角を，それぞれ $\delta_{a 1}, \delta_{c}$ とした.

また，K形継手においては，管軸方向および回転方向 の継手ばね特性は NS 形を基に設定した．K 形は離脱防 止機構を有さないため, 管軸引張方向および回転方向の 継手ば㸚定数は，小さな力で継手が伸縮，屈曲寸る領域 の值である $S_{a 1}, S_{c 1}$ のみとした．図-11に示寸通り，K形 継手の引張方向ではゴム輪の一部が挿し口と接触しなく なる継手変位を $\delta_{a 2}$ とし, 圧縮方向では挿し口が受口奥部 に接触する継手変位を $\delta_{a 3}$ とした ${ }^{8) 9}$.9.

\section{（4）地盤モデル}

図-12 に，地盤モデルの概要を示す．管路周辺地盤を ばね要素でモデル化し，管路に対して管軸方向および管 軸直交方向に接続した.

\section{a) 地盤ばね定数}

地盤ばね定数は，応答変位法による耐震計算 ${ }^{10)}$ を基に 設定した。管軸方向の地盤ばね定数 $S_{g 1}$ を式(1)で，管軸 直交方向の地盤ばね定数 $S_{\mathrm{g} 2}$ を式(2)で算出した.

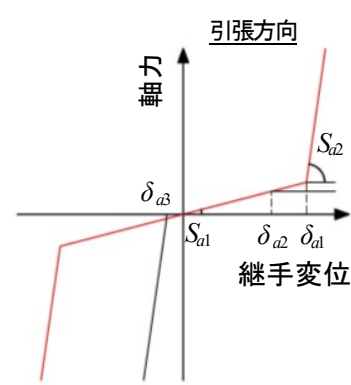

圧縮方向

管軸方向継手ばね特性

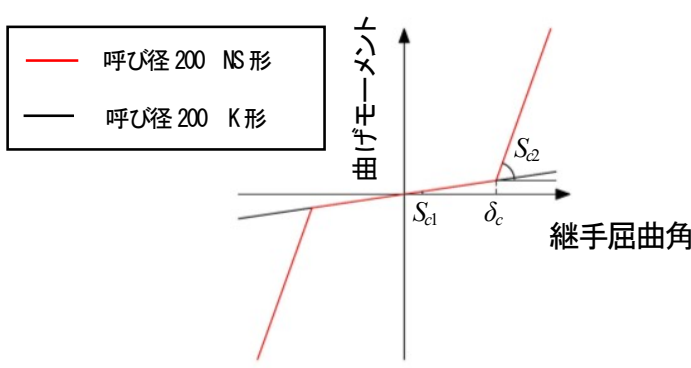

回転方向継手ばね特性

\begin{tabular}{|c|c|c|c|c|c|c|c|c|}
\hline \multicolumn{3}{|c|}{ 管軸方向ば拜 } & \multicolumn{3}{|c|}{ せん断方向ばね } & \multicolumn{3}{|c|}{ 回転方向ばね } \\
\hline$S_{a 1}$ & 832 & $(\mathrm{kN} / \mathrm{m})$ & $S_{b N S}$ & $2,496,000$ & $(\mathrm{kN} / \mathrm{m})$ & $S_{c 1}$ & 577,494 & $\left(\mathrm{kN} \cdot \mathrm{m} /{ }^{\circ}\right)$ \\
\hline$S_{a 2}$ & 281,293 & $(\mathrm{kN} / \mathrm{m})$ & $S_{b K}$ & $1,440,000$ & $(\mathrm{kN} / \mathrm{m})$ & $S_{c 2}$ & $9,236,770$ & $\left(\mathrm{kN} \cdot \mathrm{m}^{\circ}\right)$ \\
\hline$\overline{\delta_{a 1}}$ & & (mm) & & & & $\delta_{c}$ & 5.3 & (c) \\
\hline$\delta_{a 2}$ & 35 & $(\mathrm{~mm})$ & & & & & & \\
\hline$\delta_{a 3}$ & -5 & $(\mathrm{~mm})$ & & & & & & \\
\hline
\end{tabular}

図-10 ダクタイル鉄管の継手ばね特性

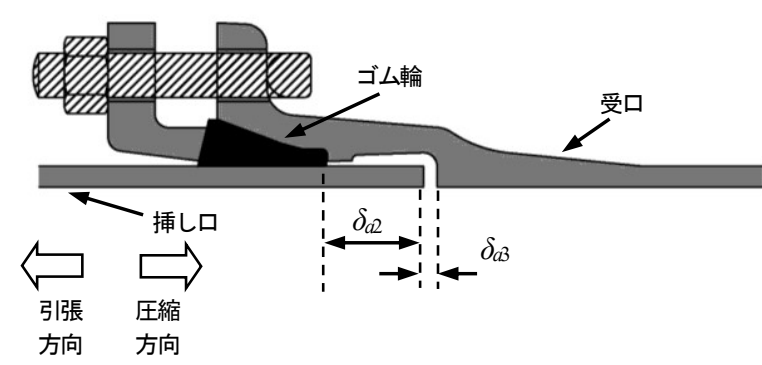

図-11 K形の継手変位

$$
\begin{aligned}
& S_{g 1}=L_{s} K_{g 1} \\
& S_{g 2}=L_{s} K_{g 2} \\
& K_{g 1}=C_{1} \frac{\gamma_{t}}{g} V_{s}^{2} \\
& K_{g 2}=C_{2} \frac{\gamma_{t}}{g} V_{s}^{2} \\
& V_{s}=61.8 N^{0.211}
\end{aligned}
$$

$L_{s}$ は 1 本の地盤ばねが受けもつ管路の単位長さであり, $100 \mathrm{~mm}$ とした． $K_{g 1}$ および $K_{g 2}$ は，それぞれ管軸方向，管 軸直交方向における単位長さあたりの地盤剛性係数であ る. $C_{1}$ および $C_{2}$ は，それぞれ管軸方向，管軸直交方向 


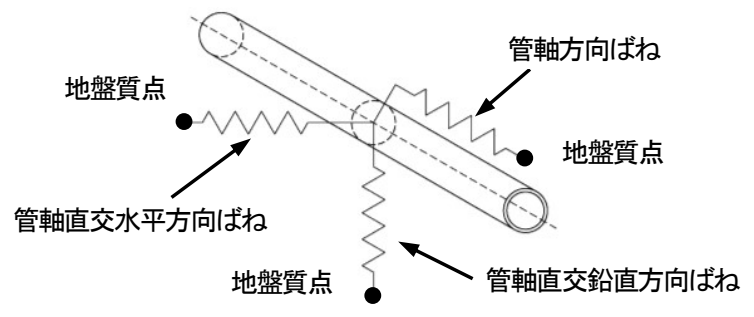

図-12＼cjkstart地盤モデル
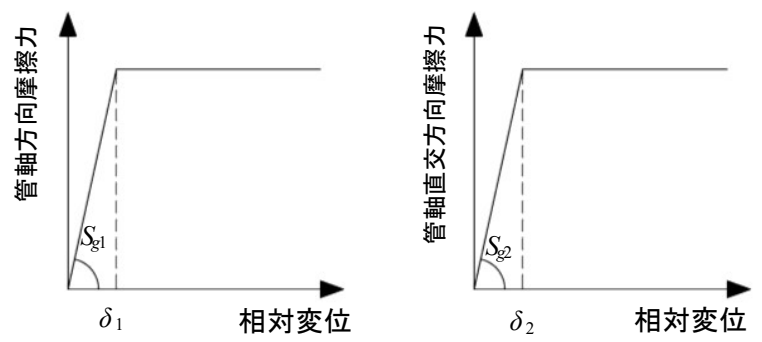

管軸方向地盤ばね特性

管軸直交方向地盤ばね特性

\begin{tabular}{|c|rc|c|rc|}
\hline \multicolumn{2}{|c|}{ 管軸方向ばね } & \multicolumn{3}{c|}{ 管軸直交方向ばね } \\
\hline$S_{g 1}$ & 2,124 & $(\mathrm{kN} / \mathrm{m})$ & $S_{g 2}$ & 4,248 & $(\mathrm{kN} / \mathrm{m})$ \\
\hline$\delta_{1}$ & 0.325 & $(\mathrm{~mm})$ & $\delta_{2}$ & 6.1 & $(\mathrm{~mm})$ \\
\hline
\end{tabular}

図-13 地盤ばね特性

における地盤剛性係数に対する定数である.一般には, $C_{1}$ は 1.5 程度， $C_{2}$ は 3 程度になることが想定されること から ${ }^{10)}, C_{1}=1.5, C_{2}=3.0$ とした. $\gamma_{t}$ は土の単位体積重量, $g$ は重力加速度， $V_{s}$ はせん断弾性波速度（単位 $\mathrm{m} / \mathrm{s}$ ) , $N$ は地盤の $\mathrm{N}$ 值である. 解析対象位置の地盤が砂質土で 構成され相対密度がゆるいものと想定して，土の単位体 積重量を $16 \mathrm{kN} / \mathrm{m}^{3}{ }^{11)}$ ，地盤の $\mathrm{N}$ 值を $7^{11)}$ とした.

本研究では，管路埋設深さより深い層が液状化するこ とで，管路は大きな地盤変状を受けるが管路周辺の地盤 は液状化しないものと想定したため，液状化に伴う地盤 ばね定数の低下を解析で考慮していない，また，地盤変 位そのものを使用して管路の挙動を検証したため，地震 時での地盤のせん断ひずみによる地盤ばね定数の低下を 考慮していない. 以上より，本研究では管路に大きな負 荷がかかる条件で管路の挙動解析を実施することとなる.

\section{b) 管と地盤との間に滑りが発生する変位}

地盤に一定以上変位が生じると，管路と地盤との間に 滑りが発生し，両者の間に相対変位が生じることとなる 管軸方向での滑りが生じる変位 $\delta_{1}$ は，水道施設耐震工 法指針10)を基に，式(6)より求めた.

$$
\delta_{1}=\frac{\pi D_{P} \tau_{c r}}{K_{g 1}}
$$

$D_{P}$ は管外径であり， $220 \mathrm{~mm}$ とした． $\tau_{c r}$ は地盤拘束力 を表し，管と地盤との間に滑りが発生した時点の值 0.01MPaを使用した.
また，管軸直交方向での滑りが生じる変位 $\delta_{2}$ は，鋼 管を対象とした地盤拘束力評価実験 ${ }^{12)} 引$ 用し, $6.1 \mathrm{~mm}$ とした．図-13に，地盤ばね特性を示寸，地盤ばね特性 は，管軸方向，管軸直交方向それぞれの地盤ばね定数 $S_{g 1}, S_{g 2}$, および滑りが生じる変位 $\delta_{1}, \delta_{2}$ より設定した.

\section{(5) 地盤変位の入力方法}

図-14 に，解析対象位置で計測された地盤変位を示寸。 地盤変位は水平方向，鉛直方向共に計測されているが， 後述する理由により，水平方向の地盤変位のみ使用した。 解析対象位置では直線上に管路が埋設されていたことか $ら^{1)}$ ，本研究では管路全長を $800 \mathrm{~m}$ と想定した．図-14中 の 7 地点で計測された水平方向の地盤変位 $D$ を, 式 (7)(8)より管軸方向の地盤変位 $D_{X}$ ，管軸直交方向の地盤 変位 $D_{Y}$ に分解した。

$$
\begin{aligned}
& D_{X}=D \cos \theta \\
& D_{Y}=D \sin \theta
\end{aligned}
$$

$\theta$ は地盤変位ベクトルと管路のなす角度である．表-1 に，解析に使用する地盤変位を示す．管軸方向は管路の 基点から終点へ向から方向を，管軸直交方向は北方向を 正とした.

なお，各計測地点間では地盤変位が計測されていない ため, 仮定の基に地盤変位を地盤質点に与える必要があ る. 本研究では, 地盤ひずみと 2 地点間の相対地盤変位 から補間距離を算出し，補間距離内で地盤変位が線形に 変化するように変位を与えた。 参考文献 5)上り, 兵庫県 南部地震時に解析対象位置であるポートアイランドの護 岸から $100 \mathrm{~m}$ 以上離れた人工島内陸部で計測された水平 方向の地盤変位より求められた地盤ひずみの最大值は, 地盤が引張方向に変位した場合, 圧縮方向に変位した場 合，共に $2.5 \%$ であった．本研究では，いずれの 2 地点 間においても，この值を使用して補間距離を求めた．以 上の仮定より, 本研究では計測された值を用いた上で, 管路に最も大きな負荷がかかる条件となる.

表-2 に地盤変位計測地点間の相対地盤変位と補間距 離を示し，図-15に一例として地点 1〜2地点間での管軸 直交方向の地盤変位を示寸. なお，地点 1〜7 はそれぞ れ地盤変位 1〜7 の計測地点である. また，一例として 地点 1〜2 間での管軸方向，管軸直交方向における相対

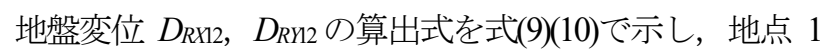
～2 間での補間距離 $L L_{12}$ の算出式を式(11)で示す.

$$
\begin{gathered}
D_{R X 12}=D_{X 2}-D_{X 1} \\
D_{R Y 2}=D_{12}-D_{11} \\
L_{12}=\frac{\sqrt{D_{R X 12}^{2}+D_{R Y 12}^{2}}}{\varepsilon_{s}}
\end{gathered}
$$




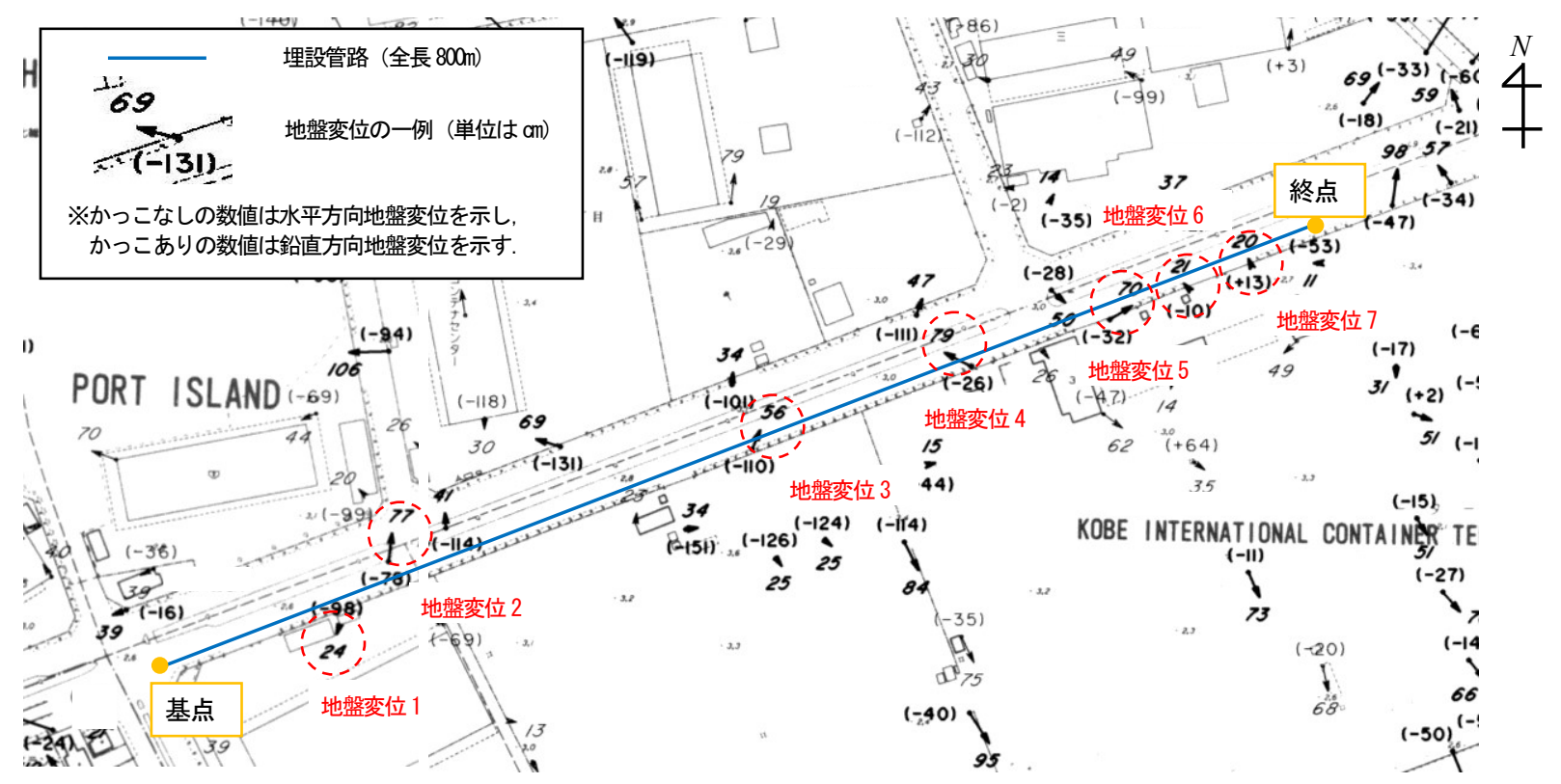

図-14 解析対象位置で計測された地盤変位 ${ }^{4}$

表-1 解析に使用寸る地盤変位

(a) 水平方向変位および地盤変位と管路のな寸角度

\begin{tabular}{|c|c|c|}
\hline & $\begin{array}{c}\text { 水平方向 } \\
\text { 変位 } \\
D\end{array}$ & $\begin{array}{c}\text { 地盤変位ベクトルと } \\
\text { 管路のなす角度 } \theta \\
(\theta \text { は管路を基準に反時計回りに算出 })\end{array}$ \\
\hline 地盤変位 1 & $24 \mathrm{~cm}$ & $236^{\circ}$ \\
\hline 地盤変位 2 & $77 \mathrm{~cm}$ & $60^{\circ}$ \\
\hline 地盤変位 3 & $56 \mathrm{~cm}$ & $45^{\circ}$ \\
\hline 地盤変位 4 & $79 \mathrm{~cm}$ & $133^{\circ}$ \\
\hline 地盤変位 5 & $70 \mathrm{~cm}$ & $9^{\circ}$ \\
\hline 地盤変位 6 & $21 \mathrm{~cm}$ & $111^{\circ}$ \\
\hline 地盤変位7 & $20 \mathrm{~cm}$ & $95^{\circ}$ \\
\hline
\end{tabular}

(b) 管軸方向地盤変位と管軸直交方向地盤変位

\begin{tabular}{|c|c|c|}
\hline & $\begin{array}{c}\text { 管軸方向 } \\
\text { 地盤変位 } D_{X}\end{array}$ & $\begin{array}{c}\text { 管軸直交方向 } \\
\text { 地盤変位 } D_{Y}\end{array}$ \\
\hline 地盤変位 1 & $-13.4 \mathrm{~cm}$ & $-19.9 \mathrm{~cm}$ \\
\hline 地盤変位 2 & $38.5 \mathrm{~cm}$ & $66.7 \mathrm{~cm}$ \\
\hline 地盤変位 3 & $39.6 \mathrm{~cm}$ & $39.6 \mathrm{~cm}$ \\
\hline 地盤変位 4 & $-53.9 \mathrm{~cm}$ & $57.8 \mathrm{~cm}$ \\
\hline 地盤変位 5 & $69.1 \mathrm{~cm}$ & $11 \mathrm{~cm}$ \\
\hline 地盤変位 6 & $-7.5 \mathrm{~cm}$ & $19.6 \mathrm{~cm}$ \\
\hline 地盤変位7 & $-1.7 \mathrm{~cm}$ & $19.9 \mathrm{~cm}$ \\
\hline
\end{tabular}

ここに，DX2，DX1 は地点 2，1 の管軸方向地盤変位， $D_{Y 2}, D_{Y 1}$ は地点 2，10管軸直交方向地盤変位， $\varepsilon_{S}$ は地盤 ひずみである。地盤ひずみは水平方向の地盤変位のみを 用いて求められたものであるため 5)，対応して相対地盤 変位も水平方向成分のみを用いた。

図-16に，解析対象位置での地盤変位を，管軸方向， 管軸直交方向それぞれで示す。この地盤変位を地盤質点 に与え，管路の挙動解析を実施した.
表-2 計測地点間の相対地盤変位と補間距離

\begin{tabular}{|c|c|c|c|}
\hline & \multicolumn{2}{|c|}{ 相対変位 } & \multirow{2}{*}{$\begin{array}{c}\text { 補間距離 } \\
L\end{array}$} \\
\hline & $\begin{array}{c}\text { 管軸方向 } \\
D_{R X}\end{array}$ & $\begin{array}{l}\text { 管軸直交 } \\
\text { 方向 } D_{R Y}\end{array}$ & \\
\hline 地点1 2間 & $51.9 \mathrm{~cm}$ & $86.6 \mathrm{~cm}$ & $40.4 \mathrm{~m}$ \\
\hline 地点2 3間 & $1.1 \mathrm{~cm}$ & $-27.1 \mathrm{~cm}$ & $10.8 \mathrm{~m}$ \\
\hline 地点3 4間 & $-93.5 \mathrm{~cm}$ & $18.2 \mathrm{~cm}$ & $38.1 \mathrm{~m}$ \\
\hline 地点4～5間 & $123 \mathrm{~cm}$ & $-46.8 \mathrm{~cm}$ & $52.7 \mathrm{~m}$ \\
\hline 地点 5 6間 & $-76.6 \mathrm{~cm}$ & $8.6 \mathrm{~cm}$ & $30.9 \mathrm{~m}$ \\
\hline 地点6〜7間 & $5.8 \mathrm{~cm}$ & $0.3 \mathrm{~cm}$ & $2.3 \mathrm{~m}$ \\
\hline
\end{tabular}

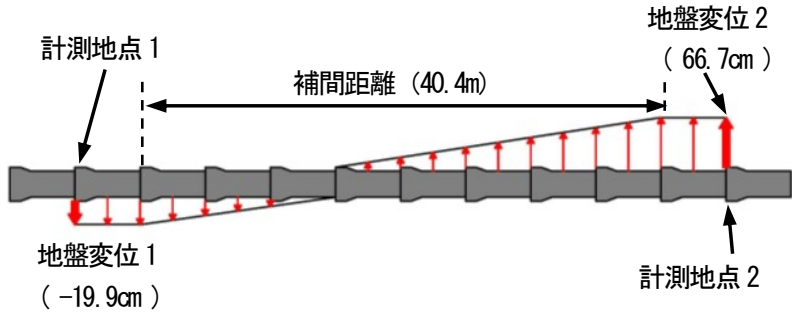

図-15２地点間での地盤変位の与え方

(地点 1 2 間の管軸直交方向の場合)

\section{3. 計測地盤変位を用いた管路の挙動解析結果}

\section{(1) $\mathrm{K}$ 形継手の挙動解析結果}

図-17 に K 形の継手伸縮量の解析結果を，解析対象位 置と併せて示す．継手の伸び量を正の值，縮み量を負の 值で表した. 水道管の被害調査 ${ }^{1)}$ より, 解析対象とした 区間のうち，赤丸で囲った範囲で継手の抜けが生じたこ とが確認されている.

図-17 より，解析では基点から 100m〜200m の区間お よび 600m〜 700mの区間で，図-18(b)に示すように一部 


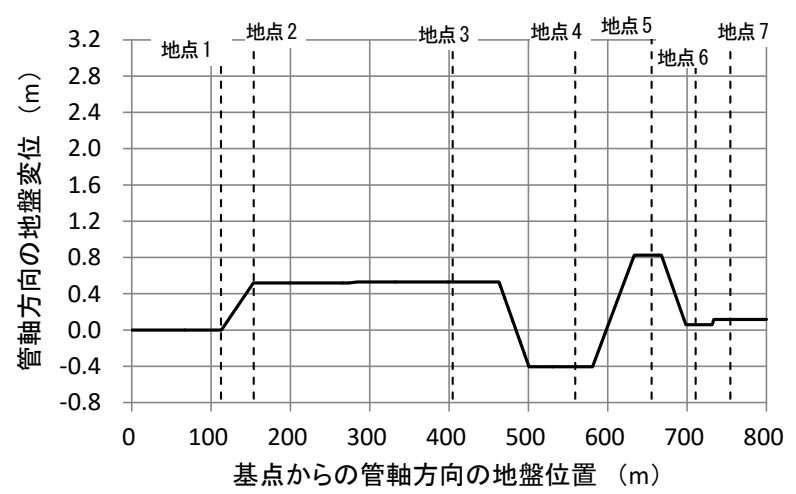

(a) 管軸方向の地盤変位

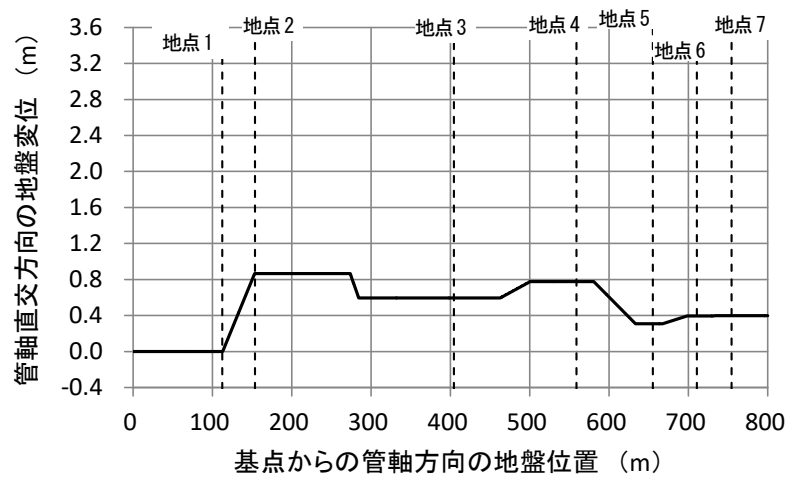

(b) 管軸直交方向の地盤変位

図-16 解析対象位置での地盤変位

の継手が抜け出す結果となった. 本研究では，解析対象 とした位置全体で地盤条件を同一としており，地盤の地 点特性を考慮していない，それを踏まえると，解析対象 位置での継手の抜けが生じた範囲と抜けが生じなかった 範囲を，解析でも定性的に再現できているため，解析手 法は妥当と判断できる.

\section{(2) NS 形継手の挙動解析結果}

本研究では，NS 形で構成された管路の安全性を評価 するため, 継手伸縮量 $\pm 52 \mathrm{~mm}{ }^{11}$ （設計照査用最大伸縮

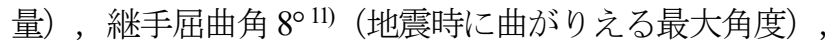
軸力 $600 \mathrm{kN}{ }^{11}$ (継手の離脱防止力 $3 D \mathrm{kN}, D$ : 呼び径 (mm))を許容值とした.

\section{a) 管路挙動}

図-19に, NS 形の管路挙動の解析結果を示す。ここで は，管軸方向，管軸直交方向の管路変位量をそれぞれ示 した．なお，管軸方向は継手が伸びる方向，管軸直交方 向は北方向を正とした. よって，図-19(a)に示寸管軸方 向の管路変位の場合，基点から離れるにつれ管路変位が 増加する区間では継手が引つ張られ，管路変位が減少す る区間では継手が圧縮されることを表す．地点 3〜地点 7 にかけて, 継手が区間ごとに交互に引張方向，圧縮方 向の力を受けていることが確認できる.
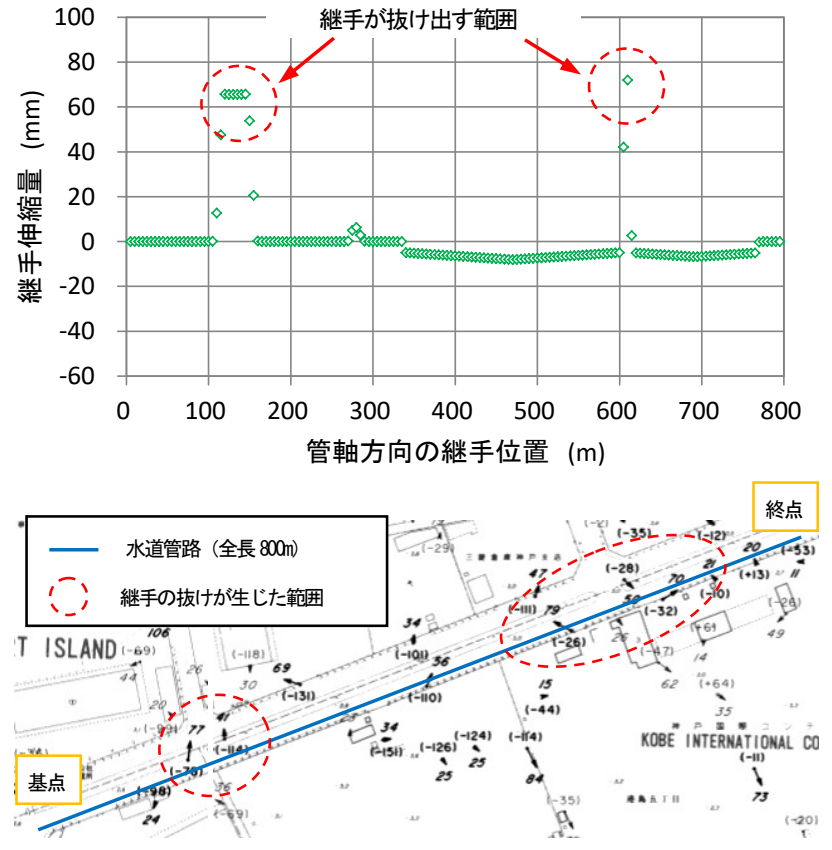

図-17 K形の継手伸縮量

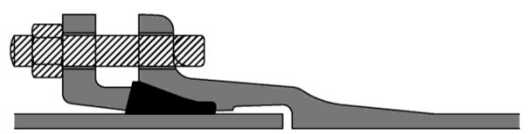

(a) 継手が接合された状態

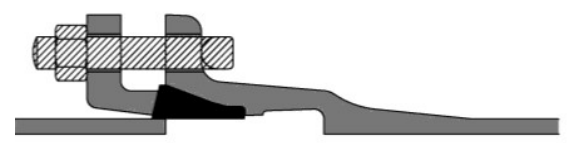

(b) 継手が抜けた状態

図-18 K形継手の状態

\section{b) 継手伸縮量}

図-20に，NS形の継手伸縮量の解析結果を示す。なお 比較対象として，K形の継手伸縮量の解析結果を併せて 示した. 結果より，NS 形の伸縮量は複数の継手で許容 值 $52 \mathrm{~mm}$ 程度まで達しており, 複数の継手が大きく伸縮 することで，地盤変位を吸収していることが確認できる．

\section{c) 継手屈曲角}

図-21に，NS形の継手屈曲角の解析結果を示寸，屈曲 角は最大でも $1.4^{\circ}$ 程度であり, 許容值 $8^{\circ}$ と比較して十分 に小さい值であった.

\section{d) 軸力}

図-22 に，NS形に発生する軸力の解析結果を示す．引 張側の軸力を正の值で，圧縮側の軸力を負の值で示した. 引張側で最大 $355 \mathrm{kN}$ 程度, 圧縮側で $325 \mathrm{kN}$ 程度の軸力が 生じているが, 許容值 $600 \mathrm{kN}$ と比較して $2 / 3$ 以下の值と なった. 


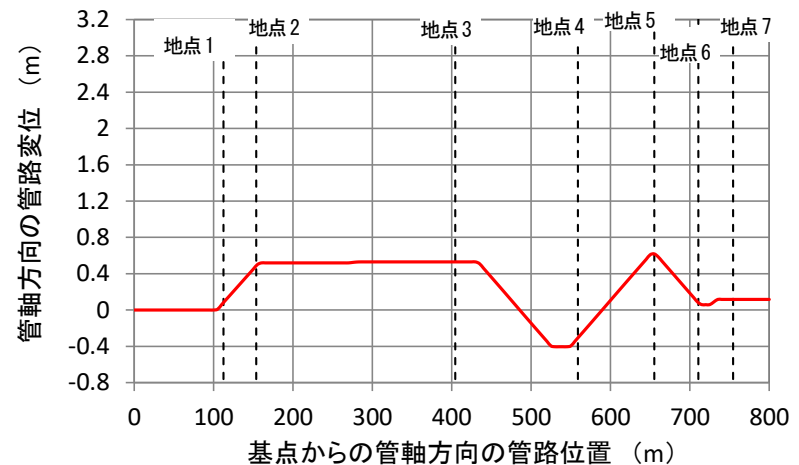

(a) 管軸方向の管路変位

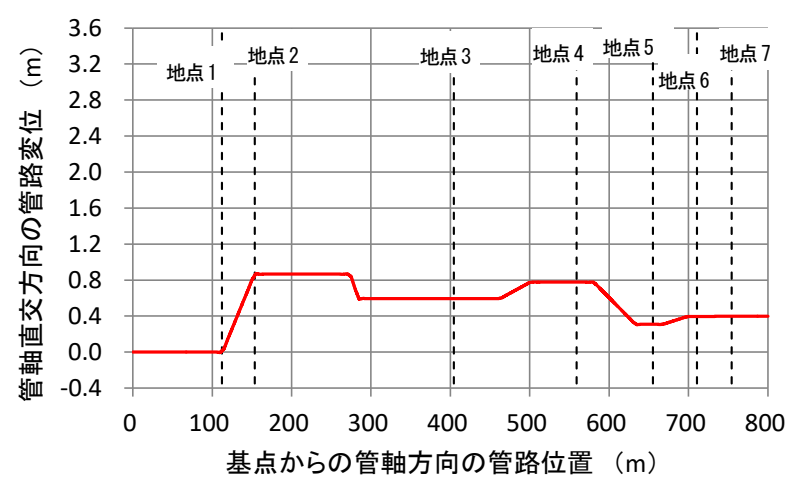

(b) 管軸直交方向の管路変位

図-19 NS 形の管路挙動

以上より，解析対象位置に仮に NS 形が埋設されてい た場合, 地震時に生じた地盤変状を受けても, 継手 1 ケ 所のみならず隣り合う継手を次々と巻き込んで挙動する 而震継手ダクタイル鉄管の性能を発揮することで，管路 の安全性を確保できることを確認できた.

\section{4. 複数回の地盤変状を受けた管路の挙動解析}

1 章で説明した通り，管路が 1 度のみならず複数回の 地盤変状を受けてどのように挙動するか明らかとなって いない，一方で，管路の使用期間内に管路が大規模な地 盤変状を複数回受けることは，十分に起こりえると考え られる．そこで本章では，1 度地盤変状を受けた NS 形 管路に対して, 同じ地盤変状を複数回与えて管路の挙動 解析を実施し，複数回の地盤変状を受けた管路がどのよ うに挙動するか検証した。

\section{（1）解析条件}

1 度地盤変状を受けた NS 形管路に対し，表-2 に示寸 地盤変位 1〜7 管路の同じ地点に繰り返し与えた.こ こでは, $i$ 回目 $(i=1,2, \cdots)$ の管路挙動結果を $i+1$ 回目 の管路の初期状態とした. 図-23に，一例として 1 度目 〜4 度目の地盤変状による, 解析対象位置での累積地盤 変位を示す。地盤変位計測地点間の補間距離等，他の入

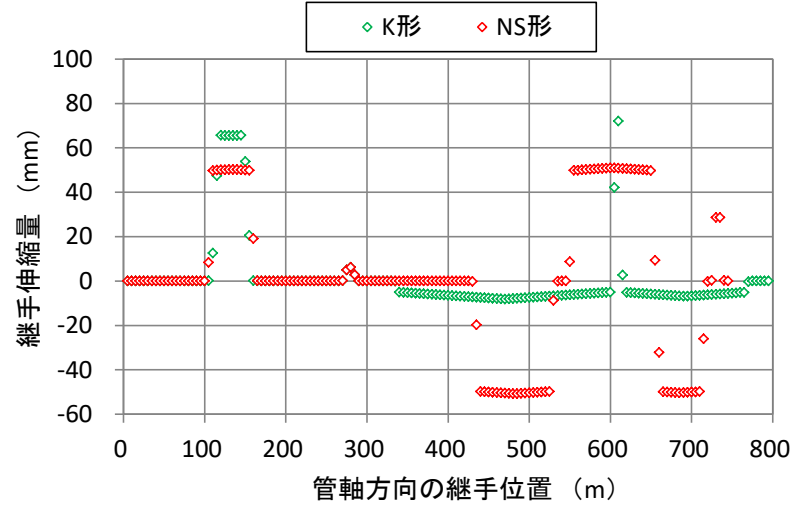

図-20 NS形の継手伸縮量

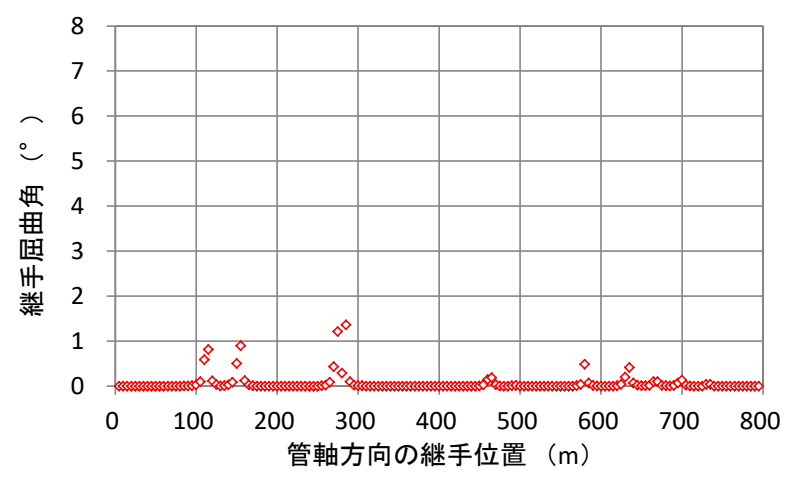

図-21 NS形の継手屈曲角

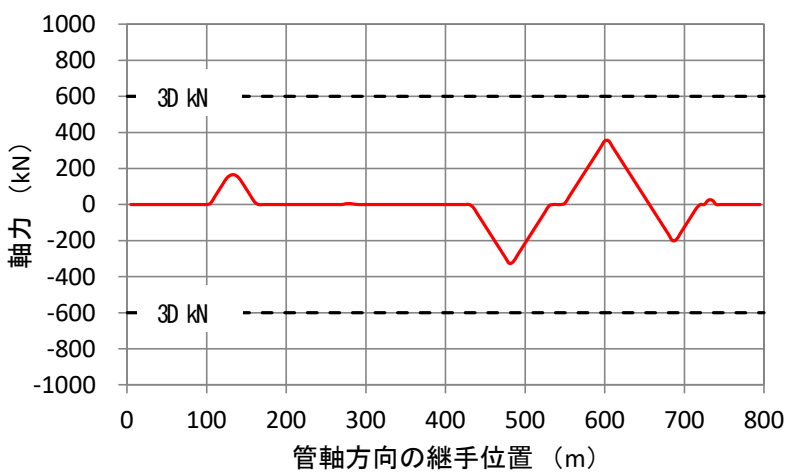

図-22 NS形に発生する軸力

力条件は 1 度目の地盤変状を受けた場合と同一であるも のとしたため，管軸方向，管軸直交方向共に， 1 度目〜 4 度目の地盤変状発生時にいずれも同じ区間内で地盤変 位が変化する条件としている．このような管路に大きな 負荷がかかる厳しい条件で, 複数回の地盤変状により継 手屈曲角および軸力がどのように変化するか検証した.

\section{(2) 解析結果}

表-3に，管路が地盤変状を受けた回数ごとに発生す る継手屈曲角および軸力の最大值を示す，なお，軸力は 引張側，圧縮側それぞれを対象とし，圧縮側の軸力は負 の值で示した. また，許容值に達したものは赤色で示し た. 表-3 の通り, 今回の検討条件では 4度目の地盤変状 を受けて軸力が許容值に達したため，本章では 1 度目〜 4 度目の地盤変状を受ける場合の解析結果を説明寸る. 


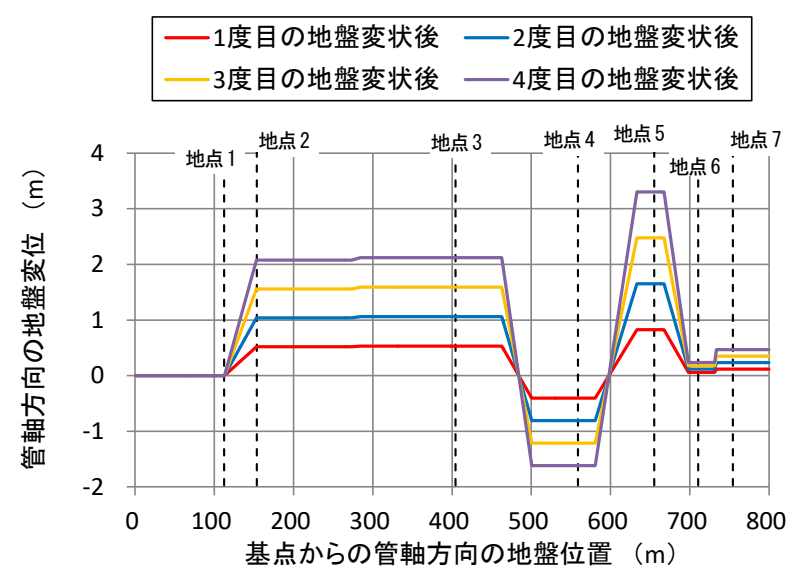

(a) 管軸方向の累積地盤変位

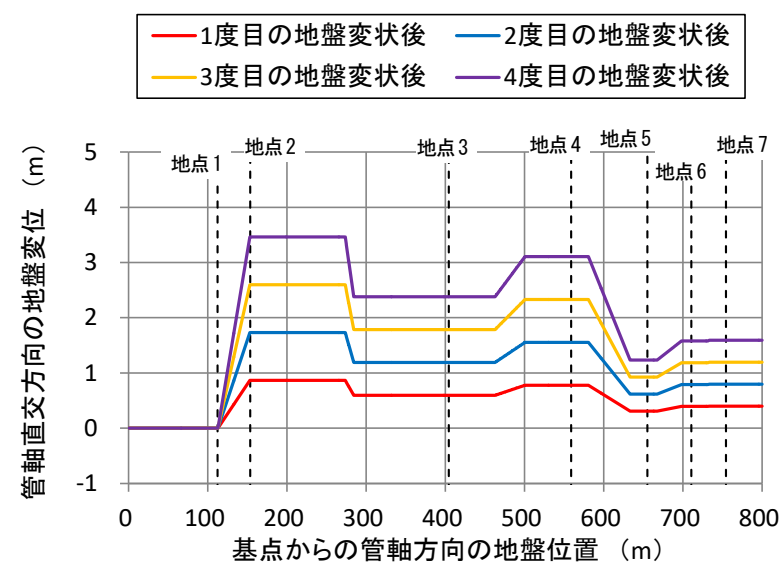

(b) 管軸直交方向の累積地盤変位

図-23 $i$ 回目 $(i=1 \sim 4)$ の地盤変状による

解析対象位置での累積地盤变位

\section{a) 管路挙動}

図-24 に，NS 形の管路挙動の解析結果を示寸. 図24(a)より管軸方向の管路挙動に着目すると，地盤変状 を受けた回数が増加するにつれ，1 ケ所の継手が伸びき る，または縮みきると隣り合う継手が次々と伸縮する耐 震継手ダクタイル鉄管の特性によって，より多くの継手 で管軸方向の地盤変位を吸収していることが確認できる. また図-24(b)より，管軸直交方向では地盤変状を受けた 回数が増加するにつれ，それぞれ 2 地点間の一定区間内 で管路変位量が同程度ずつ増加していることがわかる。

\section{b) 継手伸縮量}

図-25に, NS 形の継手伸縮量の解析結果を示寸．図25 より，基点から $0 \mathrm{~m} \sim 250 \mathrm{~m}$ の区間および 350m〜550m の区間で，地盤変状を受けた回数が増加するにつれ，許 容值 $52 \mathrm{~mm}$ 程度まで伸縮する継手が増加する結果となっ た.よって，管路が複数回の地盤変状を受けても，その 都度而震継手ダクタイル鉄管の性能を発揮して, より広 い範囲で複数の継手が伸縮し，地盤変位を吸収している ことが確認できる．一方で，基点から 550m〜 750m の区 間では，地盤変状を受けた回数が増加しても，許容值程
表-3 発生する継手屈曲角および軸力最大值

\begin{tabular}{|c|c|c|c|}
\hline 管路が地盤変状を & 継手屈曲角 & \multicolumn{2}{|c|}{ 軸力最大值 } \\
\cline { 3 - 4 } & 最大值 & 引張側 & 圧縮側 \\
\hline 1度目 & $1.4^{\circ}$ & $353 \mathrm{kN}$ & $-325 \mathrm{kN}$ \\
\hline 2 度目 & $2.7^{\circ}$ & $375 \mathrm{kN}$ & $-473 \mathrm{kN}$ \\
\hline 3 3度目 & $3.9^{\circ}$ & $563 \mathrm{kN}$ & $-545 \mathrm{kN}$ \\
\hline 4度目 & $5.2^{\circ}$ & $758 \mathrm{kN}$ & $-600 \mathrm{kN}$ \\
\hline 許容值 & $8^{\circ}$ & $600 \mathrm{kN}$ & $-600 \mathrm{kN}$ \\
\hline
\end{tabular}

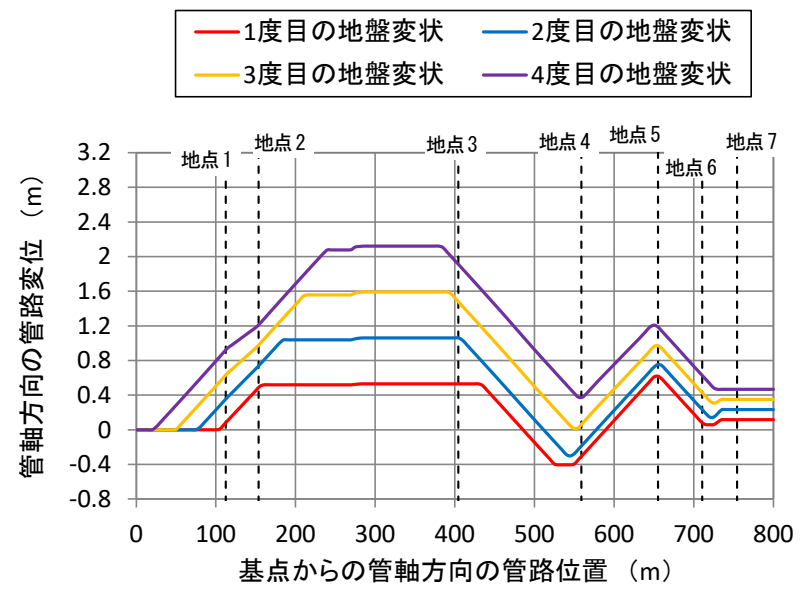

(a) 管軸方向の管路変位

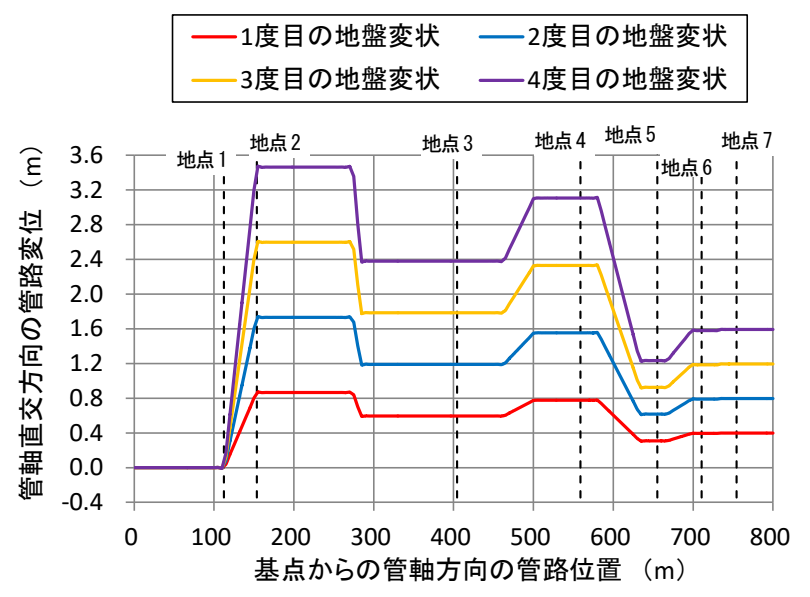

(b) 管軸直交方向の管路变位

図-24 複数回の地盤変状を受けた

NS形の管路挙動

度まで伸縮する継手の数はほとんど変化しない結果とな った.

\section{c) 継手屈曲角}

図-26に，NS形の継手屈曲角の解析結果を示寸。ここ では，継手が最も大きく屈曲した基点から $260 \mathrm{~m} \sim 300 \mathrm{~m}$ の区間に着目寸る，屈曲している継手では，地盤変状を 受けた回数が増加するにつれ，1.20程度ずつ継手屈曲角 が増加することが確認できる．なお，4 度目の地盤変状 を受けた場合の最大屈曲角は $5.2^{\circ}$ 程度であり, 許容值 $8^{\circ}$ と比較して，6割程度の值であった。 


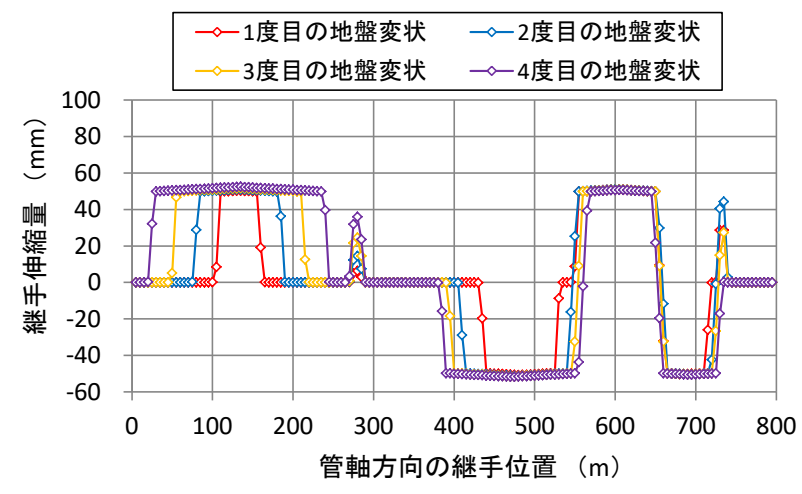

図-25 複数回の地盤変状を受けた NS形の継手伸縮量

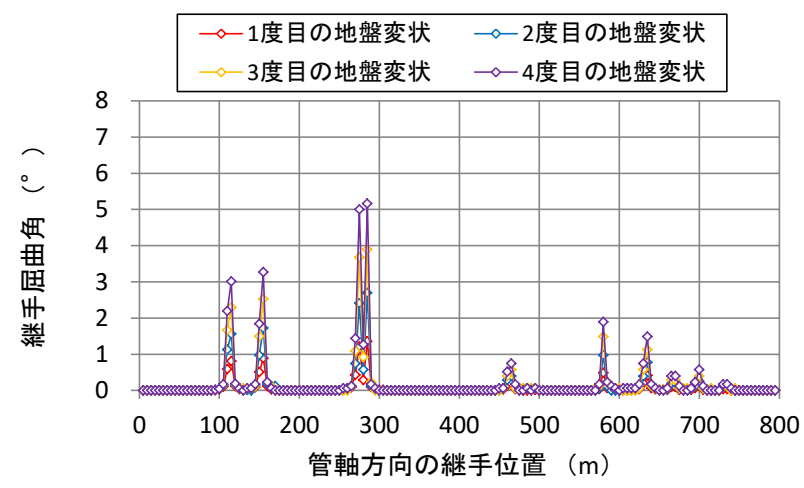

(a) 解析対象位置全域

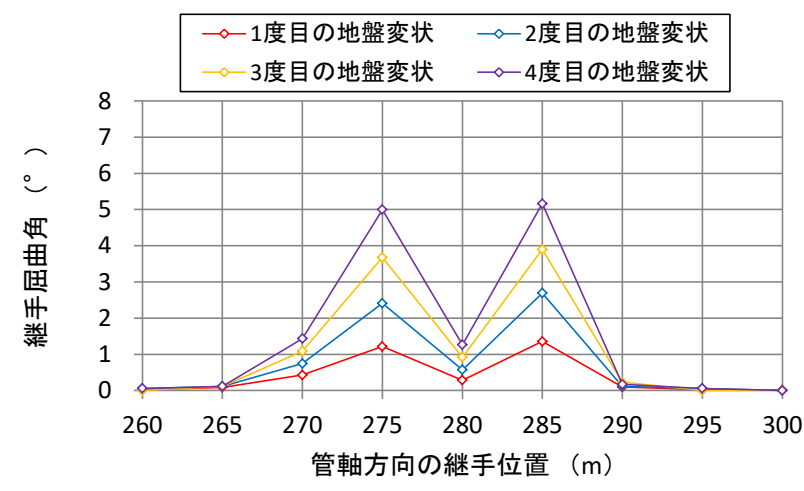

(b) 基点から 260m 300mの区間

図-26 複数回の地盤変状を受けた NS 形の継手屈曲角

\section{d) 軸力}

図-27に，NS 形に発生する軸力の解析結果を示す．地 盤変状を受けた回数が増加するにつれ，解析対象位置で の軸力最大值，および軸力発生範囲が増加することが確 認できる. 4 度目の地盤変状を受けて，基点から $100 \mathrm{~m}$ 〜200m の区間で引張側の軸力が，400m〜 $500 \mathrm{~m}$ の区間で 圧縮側の軸力が，それぞれ許容值に達する結果となった。 一方で，基点から 550m〜 750m の区間では，地盤変状を 受けた回数が増加しても，発生軸力はほとんど変化しな い結果となった.

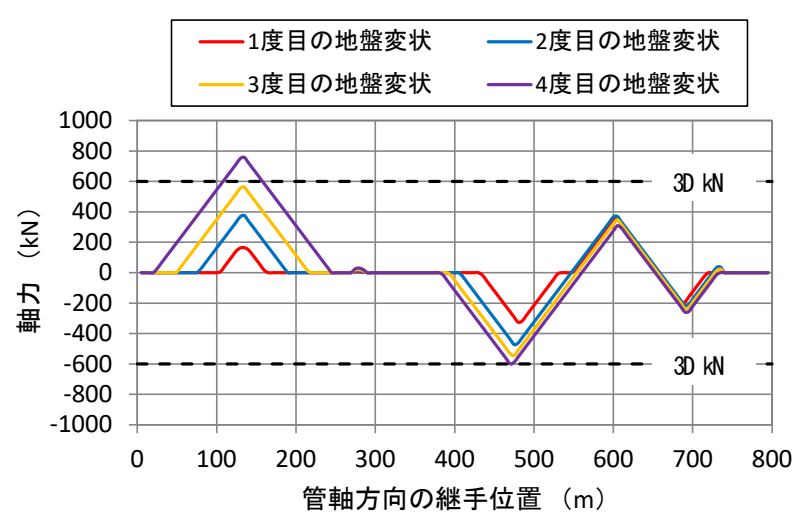

図-27 複数回の地盤変状を受けた

$\mathrm{NS}$ 形に発生する軸力

\section{(3) 考察}

複数回の地盤変状を受けた場合に，解析対象位置内の 区間によって，継手伸縮量や軸力が異なる傾向で変化す る原因を考察する. 継手伸縮量や軸力は管軸方向の管路 挙動に大きく影響を受けるため，ここでは管軸方向の管 路挙動に焦点を当てる. なお，管軸直交方向の管路挙動 については，継手が屈曲することで管軸直交方向の地盤 変位に追従すること，および複数回の地盤変状を受けて 解析対象位置内のいずれの区間においても継手屈曲角が 同じ傾向で変化することから，ここでは取り扱わないこ ととした.

図-28に，管軸方向の地盤変位と管路変位との関係を 示す．なお，地盤変位は破線で，管路変位は実線で示し た. 図-28(b)より，地盤変状を受けた回数が増加するに つれ多くの継手で伸び量が許容值近くまで達し引張側の 軸力が増加した区間 A（基点から $0 \mathrm{~m} \sim 250 \mathrm{~m}$ ）では，2 度目以降の地盤変状を受けて，地盤変位に対し管路変位 が異なる挙動を示すことがわかる，図中には，4度目の 地盤変状を受けた場合を例に，相対地盤変位が生じる範 囲，継手が伸縮する範囲をそれぞれ表記した。この範囲 では管路と地盤との間に滑りが生じており，解析対象位 置の一部で発生した大きな地盤変位を複数の継手で吸収 していることを意味する。 区間 A では，3 度目，4 度目 と地盤変状を受けるにつれ，大きな地盤変位をより広い 範囲で吸収しており，その結果，伸びきる継手が増加す ることで大きな軸力が発生し，4 度目の地盤変状を受け て管路の一部で軸力が許容值に達したと考えられる.

また図-28(c)に，地盤変状を受けた回数が増加するに つれ多くの継手で縮み量が許容值近くまで達し圧縮側の 軸力が増加した区間 B（基点から 350m〜600m）での両 者の関係を示す．地盤変状を受けた回数が増加するにつ れ，複数の継手を用いて大きな地盤変位を，より広い範 囲で吸収していることが確認できる.

一方で，図-28(d)より地盤変状を受けた回数が増加し 


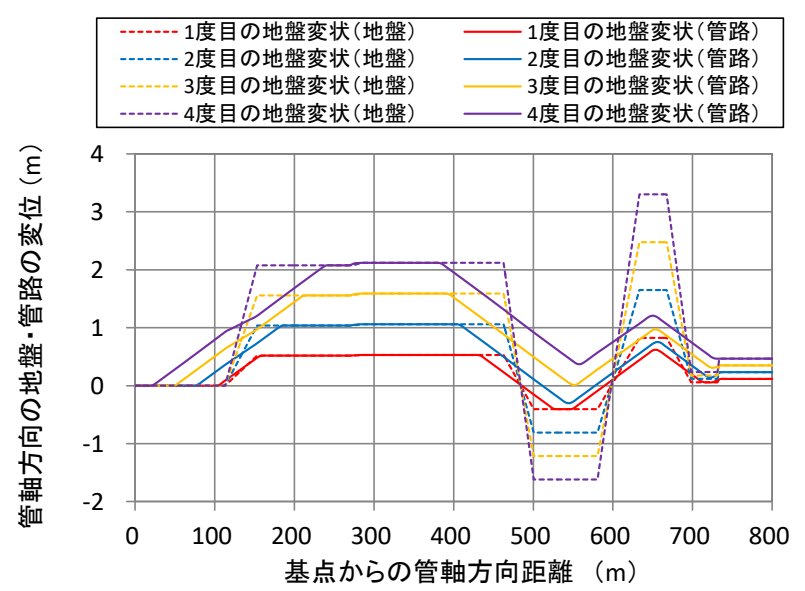

(a) 解析対象位置全域

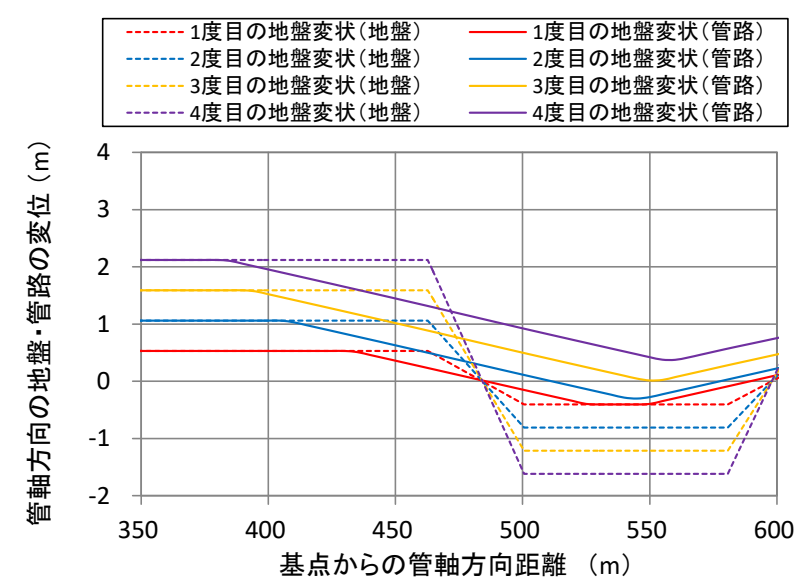

(c) 区間 B（基点から 350m〜 600mの区間）

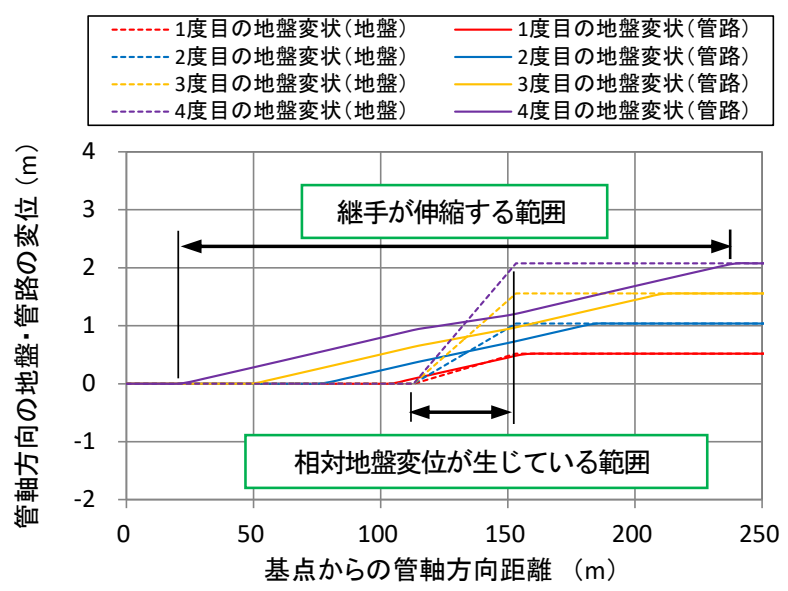

(b) 区間 $\mathrm{A}$ （基点から $0 \mathrm{~m} \sim 250 \mathrm{~m}$ の区間）

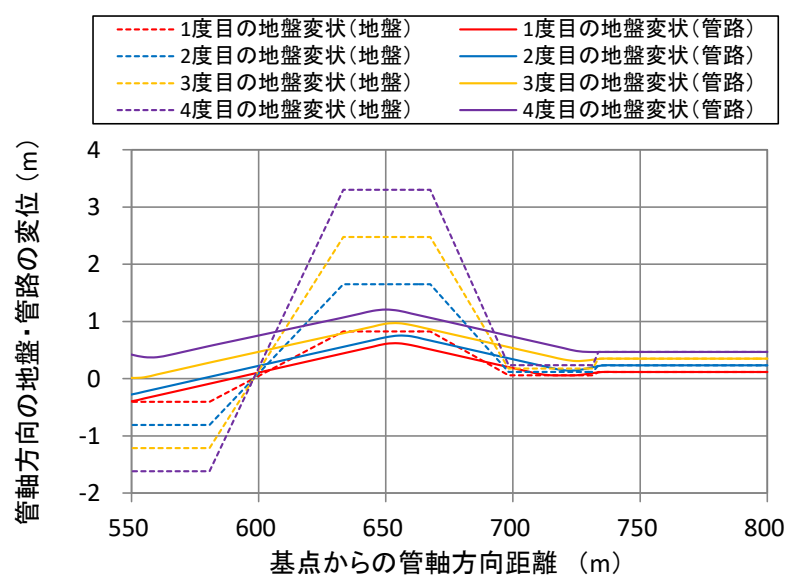

(d) 区閒 C（基点から 550m〜800m の区間）

図-28 管軸方向の地盤変位と管路変位との関係

ても許容值近くまで伸縮する継手数や軸力がほとんど変 化しない区間 C（基点から 550m〜800m）では，地盤変 位を複数の継手で吸収しているものの，1 度目の地盤変 状に対し，2 度目以降の地盤変状を受けても継手が伸縮 する範囲は大きくは変化しないことがわかる。これは， 区間 C では地盤が管軸引張方向に変位する範囲と管軸 圧縮方向に変位する範囲が近接しており，地盤変位を受 けて管路に作用する力を打ち消し合うように管路が挙動 するためと考えられる.

以上より，埋設された NS 形管が複数回の地盤変状を 受けても，而震継手ダクタイル鉄管の性能を発揮し，隣 り合う継手を次々と巻き込むように管路が挙動すること がわかった．特に，地盤が管軸引張方向に変位する範囲 と圧縮方向に変位する範囲が近接する場合といった複雑 な地盤変状下においても，その性能を十分に発揮するこ とを確認できた.

\section{5. おわりに}

兵庫県南部地震で計測された地盤変位を用いて，実際 に生じた地盤変状を管路に複数回与えて，管路の挙動解 析を実施した．本研究の結果を，以下に列挙する.

(1)解析手法の妥当性確認のため, 解析対象位置に埋設 されていたと想定される $\mathrm{K}$ 形ダクタイル鉄管が 1 度 地盤変状を受けたものとして管路の挙動解析を実施し た．解析対象とした区間のうち，地震により継手の抜 けが生じた範囲と生じなかった範囲を，解析でも定性 的に再現できたことから，解析手法の妥当性を確認で きた。

(2)同じ位置に耐震継手ダクタイル鉄管である NS 形ダク タイル鉄管が埋設されていたものと想定し，管路が 1 度地盤変状を受けたものとして管路の挙動解析を実施 したところ，NS 形に発生する継手屈曲角や発生軸力 は許容值内に収まる結果となった。仮に解析対象位置 に NS 形が埋設されていた場合，兵庫県南部地震で発 生した地盤変状を受けても，而震継手ダクタイル鉄管 の性能を発揮し，管路の安全性を確保できることを検 証できた。 
(3)1 度地盤変状を受けた NS 形管路に対し，同じ地盤変 状を複数回与えて管路の挙動解析を実施した。今回 の検討条件では，継手屈曲角よりも軸力が先に許容 值に達する結果となった。また管路が複数回の地盤 変状を受けても，その都度管路と地盤との間に滑り が生じ，隣り合う継手を次々と巻き込むように管路 が挙動することがわかつた。

本報では，1 つの地盤変状事例を対象としたが，より 強勒な管路を構築していく上では，実際に生じた他の地 盤変状による管路挙動を検証することが，重要である. そのためには，地盤変位量や地盤状況データに加え，地 盤変状を受けた管路挙動データ, 非而震管の被害状況や 被害範囲等の情報を活用できる形で記録していくことも 大切であると考える.今後は，これらの記録情報を活用 して, 様々な地盤変状事例を対象に管路の挙動を検証し, 解析手法の精度向上に取り組む.

\section{参考文献}

1) 日本水道協会：1995 年兵庫県南部地震による水道管 路の被害と分析, pp. 22-135, 1996.

2) 三浦久人：阪神・淡路大震災による耐震形ダクタイ ル鋳鉄管路の挙動調査（ポートアイランド, 六甲ア イランド），ダクタイル鉄管，第 61 号，pp. 41-48, 1996.
3) 高田至郎, 岡田健司：地中管路の耐震化 而震設計基 準の基礎と実務，pp. 133-136，岩波書店，2016.

4) 濱田政則, 磯山龍二, 若松加寿江：1995 年兵庫県南 部地震 液状化, 地盤変位及び地盤条件, pp. 134-135, 地震予知総合研究振興会, 1995.

5) Hamada, M. and O'Rourke, T. D.: Proceedings from the Sixth Japan-US Workshop on Earthquake Resistant Design of Lifeline Facilities and Countermeasures Against Soil Liquefaction, pp. 136-152, 1996.

6) 水道技術研究センター：地震による管路被害予測の 確立に向けた研究報告書, No. 2012-03, 2013.

7) 日本ダクタイル鉄管協会 : NS 形ダクタイル鉄管, pp. 1-21, 2005.

8）日本ダクタイル鉄管協会 : 便覧 第 13 版, pp. 114-301, 2018.

9）日本ダクタイル鉄管協会：K 形ダクタイル鉄管接合 要領書, pp. 10-11, 2014

10) 日本水道協会 : 水道施設耐震工法指針 - 解説 I 総論 2009 年版, pp. 61-91, 2009.

11）日本ダクタイル鉄管協会 : NS 形・S 形ダクタイル鉄 管管路の設計, pp. 4-15, 2016.

12) 安藤広和, 小林実央, 小口憲武 : 地震時地盤の側方 変位により埋設管に作用する拘束力の検討, 地震工 学研究発表会講演概要, 第 23 巻, pp. 409-412, 1995.

(2018.11.1 受付, 2019.1.15 修正, 2019.2.17 受理)

\section{STUDY ON BEHAVIOR OF SEISMIC TYPE DUCTILE IRON PIPES INFLUENCED BY MULTIPLE GROUND DEFORMATION IN LIQUEFIED GROUND}

\section{Koichi MORIMOTO and Masakatsu MIYAJIMA}

In earthquake, liquefaction have caused large-scale ground deformation in the soft ground. Therefore, buried water pipelines were damaged seriously. Seismic type ductile iron pipes have never damaged because those joints have extension and contraction function, bend performance, and separation preventing performance. However, we have not clarified how pipelines behave when they were influenced by multiple ground deformation. In this study, we analyzed the behavior of pipeline composed of seismic type ductile iron pipes when the pipelines were influenced by multiple ground deformation, using ground displacement measured at the 1995 Hyogoken-Nanbu Earthquake. 